\title{
Application of Clustering System to Analyze Geological, Geotechnical and Hydrogeological Data Base according to HC-System Approach
}

\author{
Lilik Eko WIDODO $^{a}$, Tedy Agung CAHYADI ${ }^{b}$, Sudarto NOTOSISWOYO $^{a}$, Eman WIDIJANTO $^{b}$ \\ ${ }^{a}$ Lecturer, Mining Engineering ITB, Indonesia \\ ${ }^{b}$ PhD Student, Mining Engineering ITB, Indonesia \\ * tedyagungc.students.itb@gmail.com (corresponding author's e-mail)
}

\begin{abstract}
Highly fractured rocks at Grasberg Mining in PT Freeport Indonesia (PTFI) lead to fractured groundwater flow media. Hydraulic conductivity of fractured rock has more complexity than that of porous rocks media. In this study, hydraulic conductivity $(\mathrm{K})$ has been estimated according to HC-System based on Rock Quality Designation (RQD), Lithology Permeability Index (LPI), Depth Index (DI) and Gouge Content Designation (GCD). Numerical model of HC-System at Grasberg Mining in general can be expressed by the equation $\mathrm{K}=2 \times 10^{-6} \times \mathrm{HC}^{0.5571}$. The RQD data can be grouped into three ranges, i.e. first group that dominates over $80 \%$ of the RQD data with $\mathrm{K}$ ranging between $1.9 \times 10^{-8}$ $-2.3 \times 10^{-7} \mathrm{~m} / \mathrm{s}$, second group that is within $40-80 \%$ of the RQD data with $\mathrm{K}$ falling between $2 \times 10^{-8}$ $7.2 \times 10^{-7} \mathrm{~m} / \mathrm{s}$, and third group that takes part less than $40 \%$ of RQD data with $\mathrm{K}$ ranging between $2.1 \times 10^{-8}-1.9 \times 10^{-6} \mathrm{~m} / \mathrm{s}$. Based on the lithology, the hydraulic conductivity of rocks can be assinged as follows: igneous rock with $\mathrm{K}$ ranging $6.8 \times 10^{-8}-1.9 \times 10^{-7} \mathrm{~m} / \mathrm{s}$, and sedimentary rock with $\mathrm{K}$ ranging $2.2 \times 10^{-8}-1.9 \times 10^{-6} \mathrm{~m} / \mathrm{s}$. HC-System demonstrates good interpretation of hydraulic conductivity by means of clustering method, which uses geological and geotechnical data for hydrogeological characterization.
\end{abstract}

Keywords: clustering, hydraulic conductivity, HC-System, RQD, lithology

\section{Introduction}

The Grasberg mine of PTFI is one of the largest mines in the world. It is located between the confluence of several faults that lead to fractured rocks. In the Grasberg mine design process, it was required geological, geotechnical and hydrogeological data acquisition. Based on the results of drilling activities at Grasberg mine, a lot of information can be described for characterization of the hydrogeological conditions. Accordingly, by using HC-System (Hsu et al, 2011), 441 information from geotechnical drilling or as much as 4,850 points of data have been used to model hydraulic conductivity distribution based on RQD, LPI, DI, GCD data (Cahyadi et al, 2015).

Cluster analysis is a technique to divide the data into several groups with similar condition (Jain et al, 1999). Cluster analysis-based only describes a similar relationship, with the greater similarity (or homogeneity) within a group and greater the difference between group. The geological cluster analysis demonstrated relationship between intrusive contacts with increasing parameter hydraulic conductivity such us hydraulic conductivity in identifying hydrogeological characterization (Mayer et al, 2014).

The purpose of this study is to understand the relationship between hydrogeological and geological (lithology) as well as geotechnical (RQD) condition based on data from bore holes by means of clustering analysis.

\section{Study Site}

Data for this study were collected at Grasberg Mine. According Sapiie et al (1994), most of the faults in Grasberg Mine can be grouped as left lateral slip fault. The stratigraphy consists of 4 groups, such as Kembelangan Group (Jurazic - Cretazeus), New Guinea Limestone (Palaeocene-Meocene), Intrusion (Tersier) and Glacial (Quarter) on the top. The main fault includes Barat Laut, Merren Valley 1 \& 2, Fairly Lake, Idenberg $1 \&$ 2, Big Gossan and Hertzberg trending East - West $\left(\mathrm{N} 120^{\circ} \mathrm{E}-\mathrm{N} 150^{\circ} \mathrm{E}\right.$ and $\mathrm{N} 250^{\circ} \mathrm{E}$ ), which can be classified as left lateral slip fault. Major faults are cut by faults trending $\mathrm{N} 050^{\circ}$ $\mathrm{E}-\mathrm{N} 070^{\circ} \mathrm{E}$ and $\mathrm{N} 350^{\circ} \mathrm{E}$ that consist of Grasberg, Cartenz Valley and New Zealand Pass. As a result of the intersection of faults, in Kembelangan Group and New Guinea Limestone occured intrusion consisting of Dalam Intrusion, Main Grasberg Intrusion, Kali Intrusion. Stratigraphy in Grasberg and surrounding can be described from youngest to oldest age as follows: Alluvial (quaternary alluvial, colluvium, and glacial), Intrusion (Kali, Main Grasberg Intrusion, Dalam), Kais Formation (limestone 
with low and high fracture as well as coarse fragmentation), Sirga Formation (sandstones with medium to coarse fragmentation), Faumai Formation (massive limestone), Waripi Formations (dolomite), Ekmai Formation (massive limestone), Piniya Formation (mudstone), Woniwogi Formation (sandstone) and Kopai Formation (sandstone).

Rainfall condition is high, of more than $4,000 \mathrm{~mm} /$ year, with 1,470 ha catchment area. The rainfall results in the quantity of precipitation of arround $25,500 \mathrm{gpm}$, from which $55 \%$ runs off (Antoro et al, 2011). Groundwater flow is controlled by secondary aquifer, that is caused by interconnection of fractures. According to monitoring on January 2013, groundwater table position ranges between $8 \mathrm{~m}$ until $478 \mathrm{~m}$ from the surface.

\section{Methodology}

\subsection{Hydrogeological data collection}

Hydraulic conductivity data was collected using packer test and slug test. Packer test results are available from 2 boreholes and 18 target points. Moreover, slug test results are available from 31 boreholes. Model of isotropic hydraulic conductivity based on the information of Rock Quality Designation (RQD), Lithology Permeability Index (LPI), Depth Index (DI) and Gouge Content Index (GCI) can be resulted at 441 drill holes or 4,850 points. Data from 441 drill holes have been analysed in detail, so that it can be used to determine the relationship between hydrogeological, geological and geotechnical condition. Following Cahyadi et al (2015), hydraulic conductivity at drill holes were distributed by HC-System using equation $\mathrm{K}=2 \times 10^{-6} \times \mathrm{HC}^{0,5571}$.

\subsection{HC-System}

HC-System approach (Hsu et al, 2011) was developed according to the packer test and slug test using geotechnical data from drilling, such as Rock Quality Designation (RQD), Lithology Permeability Index (LPI), Depth Index (DI), and Gouge Content Designation (GCD). HC-Index is an empirical method to estimate HC-Value (HC). In this study, it was put in a scatter plot along with hydraulic conductivity obtained from testing directly in the field using packer test and slug test. The HC-Value was expressed by using equation (1) below.

$$
H C=\left(1-\frac{R Q D}{100}\right) \cdot(D I) \cdot(1-G C D) \cdot(L P I)
$$

Where:

$$
\begin{array}{ll}
\text { HC } & \text { : HC-Value } \\
\text { RQD } & \text { : rock quality designation } \\
\text { DI } & \text { : depth index } \\
\text { GCD } & \text { : gouge content designation } \\
\text { LPI } & \text { : lithology permeability index }
\end{array}
$$

RQD value is an indicator of rock mass condition in term of fragmentation within it. From hydrogeological point of view, fractured rock mass ore later on known as fractured media has more ability to transmit water from and into the formation than ordinary porous media. Following Deere et al (1967), the RQD value was defined as the cumulative length of core pieces longer than $100 \mathrm{~mm}$ in a run $\left(R_{S}\right)$ divided by the total length of the core run $\left(R_{T}\right)$ and can be expressed in the equation $(2)$. In geotechnical analysis, RQD is useful for defined Rock Mass Quality (Table 1 and Figure 1). In Grasberg Mine, aquifer is controlled by interconnection of fractures. RQD can be used to represent the secondary aquifer on site as it may contain signifigant groundwater.

Table 1. RQD classification index (Deere et al, 1989)

\begin{tabular}{ll}
\hline RQD & Rock mass quality \\
\hline$<25 \%$ & very poor \\
$25-50 \%$ & Poor \\
$50-75 \%$ & Fair \\
$75-90 \%$ & Good \\
$90-100 \%$ & Excellent \\
\hline
\end{tabular}




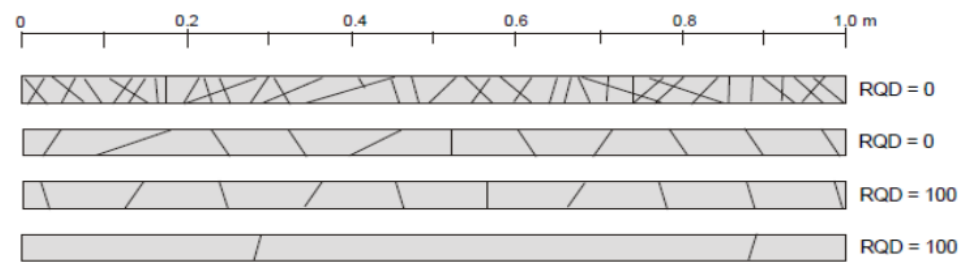

Figure 1. RQD value for various joint densities along drill cores (Deere et al, 1989)

$R Q D=\frac{\sum R_{S}}{R_{T}} \times 100 \%$

The decrease in permeability with depth in fractured rocks is usually attributed to reduction in fracture aperture and fracture spacing. The depth may be considered as a factor in evaluating rock mass permeability (Lee et al, 1993). To assess the influence of the depth on permeability, a depth index, namely $D I$, was defined according Hsu et al (2011) as follows.

$D I=1-\frac{L_{C}}{L_{T}}$

in which $L_{T}$ is the total length of a borehole; $L_{c}$ is a depth which is located at the middle of a double packer test interval in the borehole.

The $R Q D$ value may decrease by increasing number of fractures in a core run. If the fractures contain infillings such as gouges, the hydraulic conductivity of the rock decreases because the cracked rock is blocked by filling material. GCD cannot be obtained from drill log. It means that GCD does not present on core run. It has been assumed to be proportional with RQD (Cahyadi et al, 2015). Accordingly, when RQD value is greater, $90 \%-100 \%$, the permeability decreases then the GCD value is set to be within $0,9-1$.

Lithology is an intrinsic character of a rock in terms of mineral composition and grain size. For an intact rock, the magnitude of permeability depends largely on the individual character of the rock matrices. It may be affected by the average size of the pores, which in turn is related to the distribution of particle sizes and particle shape. To assess the influence of lithology on permeability, a lithology permeability index (LPI) was defined as shown in Table 2 according Hsu et al (2011).

Table 2 Rating for LPI values based on lithology in the study area (Cahyadi et al, 2015)

\begin{tabular}{lclc}
\hline \multicolumn{1}{c}{ Lithology } & Suggest Rating & \multicolumn{1}{c}{ Lithology } & Suggest Rating \\
\hline Andesite & 0.15 & Sandy dolomite & 0.95 \\
\hline Trachyandesite & 0.15 & Silty dolomitey & 0.95 \\
\hline Hydrothermal breccia & 0.1 & Gravel & 1 \\
\hline Intrusive breccia & 0.1 & Limestone & 0.7 \\
\hline Diorite & 0.15 & Limestone breccia & 1 \\
\hline Porphyritic diorite & 0.15 & Dolomitic limestone & 0.7 \\
\hline Monzonite & 0.15 & Sandy limestone & 0.4 \\
\hline Porphyritic monzonite & 0.1 & Silty limestone & 0.3 \\
\hline Quartz diorite & 0.15 & Mudstone & 0.3 \\
\hline Quartz diorite porphyritic & 0.15 & Shale & 0.5 \\
\hline Quartz monzonite & 0.15 & Shale carbonaceous & 0.75 \\
\hline Quartz monzonite porphyritic & 0.15 & Shale limey & 0.6 \\
\hline Tuff & 1 & Sandstone & 1 \\
\hline Alluvium & 1 & Limestone sandstone & 0.95 \\
\hline Colluvium & 1 & Sandstone breccia & 1 \\
\hline Rehandle Material & 1 & Sandstone breccia & 1 \\
\hline
\end{tabular}




\begin{tabular}{lclc}
\hline \multicolumn{1}{c}{ Lithology } & Suggest Rating & \multicolumn{1}{c}{ Lithology } & Suggest Rating \\
\hline Sedimentary breccia & 1 & Limey sandstone & 0.3 \\
\hline Tectonic breccia & 1 & Silty sandstone & 0.3 \\
\hline Conglomerate & 1 & Siltstone & 0.3 \\
\hline Clay & 0.3 & Dolomitic siltstone & 0.2 \\
\hline Dolomite & 0.7 & Limey siltstone & 0.3 \\
\hline Dolomite breccia & 0.85 & Sandy siltstone & 0.2 \\
\hline Limey dolomite & 0.7 & & \\
\hline
\end{tabular}

\subsection{Clustering}

The method of clustering can be classified between two primary group of clusters: hierarchical and partitional method. A partitional clustering is simply division of set of data object into non overlapping subsets (cluster) such that each data object is in exactly one subset (Jain et al, 1999), for example, any distribution lithology at some place. Different physic shape can be clustered to 3 clusters such us igneous rock, sediment rock and metamorphic rock. It is simple way for clustering method that was called partitional method.

In this study, the clusters were used to identify relationship between hydraulic conductivity between geological such us lithology, and geotechnical such us RQD. Based on HC-System, hydraulic conductivity at drill holes can be estimated (Cahyadi et al, 2015). Two partitional clusters method were performed in this study. The first (geotechnical cluster) was used to cluster the hydraulic conductivity based on the Rock Quality Designation (RQD). From hydrogeological view point, any relationship exists between fracture and hydraulic conductivity. The greater the value of RQD will decrease permeability values and otherwise. The second cluster (geological cluster) was used to cluster the hydraulic based on the geological log for the boreholes (lithology).

All clusters were completed using filtering method on EXCEL spreadsheet program. Hydraulic conductivity from slug test and packer test were modeled to get HC-System equation, then hydraulic conductivity of every point in borehole can estimated. The RQD and lithology data from boreholes for slug and packer tests were then captured for clustering of hydraulic conductivity using partition method.

\section{Result and Discussion}

\subsection{Hydraulic Conductivity Model based on the HC-System}

From boreholes data, type of lithology, mineral, RQD and the position of core can be identified. Cahyadi et al (2015) have modeled values of hydraulic conductivity in the Grasberg open pit using the equation $\mathrm{K}=2 \times 10^{-6} \times \mathrm{HC}^{0,5571}$ according to HC-System. The equation was then used to predict the value of hydraulic conductivity along 441 drilling points or 4,850 points of cores. The corresponding relationship between RQD, GCD, DI, HC-Index and hydraulic conductivity is shown at Table 2.

Figure 2 shows scatter plot of RQD, LPI and DI against measured hydraulic conductivity. From figure 2 , it can be seen that RQD and hydraulic conductivity are closely correlated with value determination coefficient of 0.82 or correlation coefficient of 0.91 . LPI and hydraulic conductivity have a coefficient of determination of 0.52 or correlation coefficient of 0.72 . From both correlation, it can be concluded that RQD have more dominant effect on the flow of groundwater in the fractured rock, while the DI is poorly correlated to the hydraulic conductivity with determination coefficient of 0.02 and correlation coefficient of 0.14 . It is possibly due to the geological structures or forces that may alter the compacted rocks to become the fractured rock. 

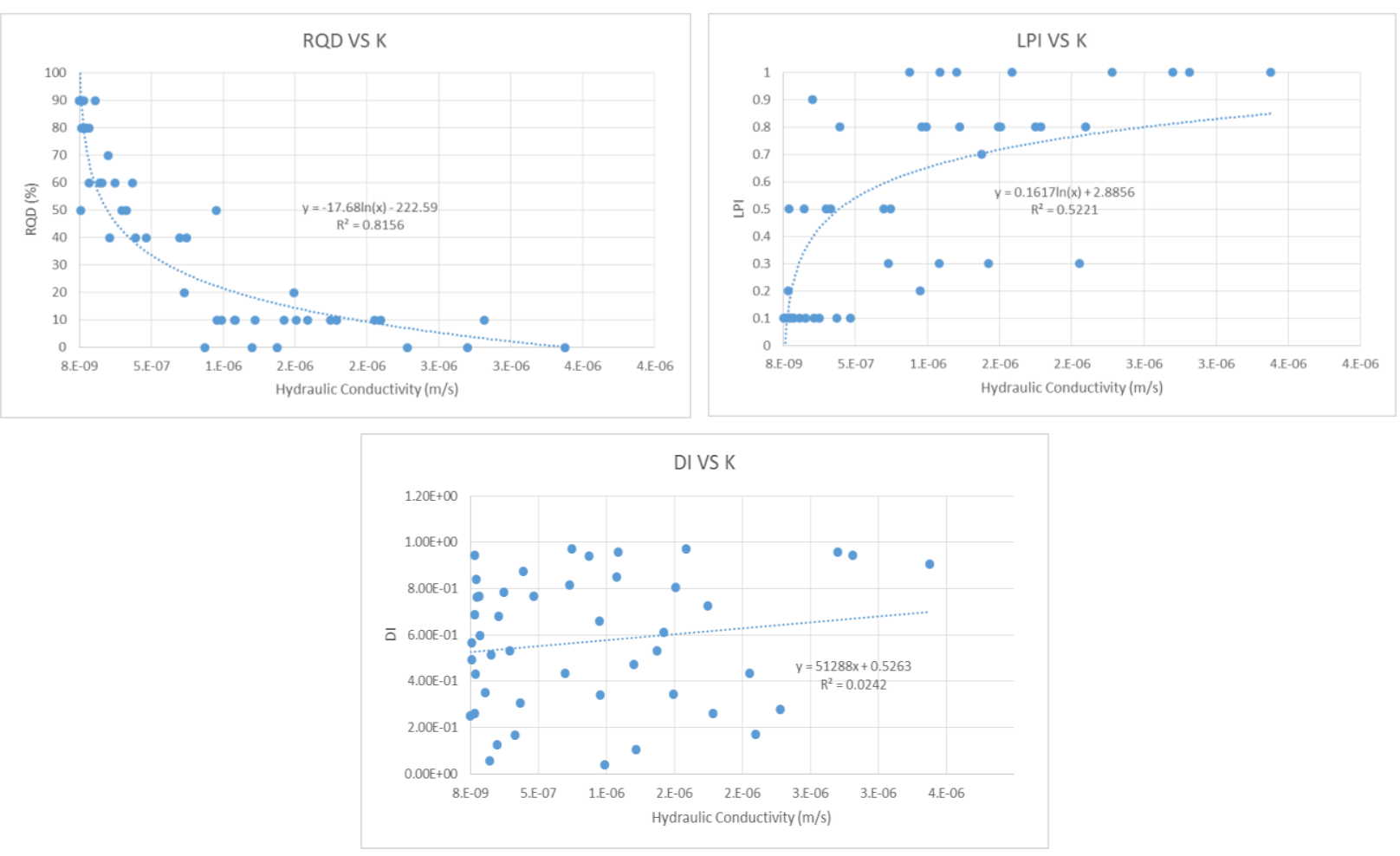

Figure 2. Relationship between hydraulic conductivity and RQD, LPI, DI

Table 2. Result of calculation of HC-Values in each packer and slug test zone (Cahyadi et al, 2015)

\begin{tabular}{|c|c|c|c|c|c|c|c|c|c|}
\hline Hole ID & Lithology & $\begin{array}{c}\text { K Packer \& } \\
\text { Slug Test }(\mathbf{m} / \mathbf{s})\end{array}$ & $\begin{array}{c}\text { Point } \\
\text { Test }\end{array}$ & $\begin{array}{c}\text { Total } \\
\text { Depth } \\
(\mathbf{m})\end{array}$ & 1-(RQD/100) & DI & 1-GCD & LPI & $\mathrm{HC}$ \\
\hline VZW-094 & Hornblende Trachyandesite & 5.79E-06 & 23.25 & 300 & 0.9 & 0.92 & 0.9 & 0.8 & 0.59778 \\
\hline VZW-094 & Volcanic Breccia & 4.73E-07 & 69.85 & 300 & 0.6 & 0.76 & 0.6 & 0.1 & 0.02762 \\
\hline VZW-094 & Volcanic Breccia & $2.16 \mathrm{E}-07$ & 95.5 & 300 & 0.6 & 0.68 & 0.6 & 0.1 & 0.02454 \\
\hline VZW-094 & Volcanic Breccia & $7.78 \mathrm{E}-08$ & 120.5 & 300 & 0.4 & 0.59 & 0.4 & 0.1 & 0.00957 \\
\hline VZW-094 & Volcanic Breccia & $1.63 \mathrm{E}-07$ & 145.5 & 300 & 0.4 & 0.52 & 0.4 & 0.1 & 0.00824 \\
\hline VZW-094 & Volcanic Breccia & $4.54 \mathrm{E}-08$ & 170.5 & 300 & 0.2 & 0.43 & 0.2 & 0.1 & 0.00173 \\
\hline VZW-094 & Skarn & $1.50 \mathrm{E}-06$ & 196.5 & 300 & 0.8 & 0.34 & 0.8 & 0.8 & 0.17664 \\
\hline VZW-094 & Limestone & 4.27E- 08 & 221.5 & 300 & 0.2 & 0.26 & 0.2 & 0.5 & 0.00523 \\
\hline VZW-094 & Limestone & 3.37E-07 & 250 & 300 & 0.5 & 0.16 & 0.5 & 0.5 & 0.02083 \\
\hline VZW-094 & Limestone & $1.51 \mathrm{E}-07$ & 283.5 & 300 & 0.4 & 0.05 & 0.4 & 0.5 & 0.0044 \\
\hline GHD-3885-26 & Volcanic Breccia & $1.08 \mathrm{E}-06$ & 29.95 & 200 & 0.9 & 0.85 & 0.9 & 0.3 & 0.20661 \\
\hline GHD-3885-26 & Volcanic Breccia & $1.43 \mathrm{E}-06$ & 77.75 & 200 & 0.9 & 0.61 & 0.9 & 0.3 & 0.14853 \\
\hline GHD-3885-26 & Volcanic Breccia & $2.06 \mathrm{E}-06$ & 113.2 & 200 & 0.9 & 0.43 & 0.9 & 0.3 & 0.10546 \\
\hline GHD-3885-26 & Hornblende Trachyandesite & $9.64 \mathrm{E}-07$ & 132.2 & 200 & 0.9 & 0.33 & 0.9 & 0.8 & 0.21967 \\
\hline GHD-3885-26 & Hornblende Trachyandesite & $1.79 \mathrm{E}-06$ & 147.75 & 200 & 0.9 & 0.26 & 0.9 & 0.8 & 0.16929 \\
\hline GHD-3885-26 & Hornblende Trachyandesite & $2.11 \mathrm{E}-06$ & 166 & 200 & 0.9 & 0.17 & 0.9 & 0.8 & 0.11016 \\
\hline GHD-3885-26 & Hornblende Trachyandesite & $1.23 \mathrm{E}-06$ & 179.2 & 200 & 0.9 & 0.10 & 0.9 & 0.8 & 0.06739 \\
\hline GHD-3885-26 & Hornblende Trachyandesite & $9.97 \mathrm{E}-07$ & 192.5 & 200 & 0.9 & 0.03 & 0.9 & 0.8 & 0.0243 \\
\hline CSTG-01 & Alluvium & $3.98 \mathrm{E}-07$ & 17.05 & 137.5 & 0.6 & 0.87 & 0.6 & 0.8 & 0.25229 \\
\hline CSTG-02B & Alluvium & $1.75 \mathrm{E}-06$ & 29.71 & 108.5 & 0.9 & 0.72 & 0.9 & 0.8 & 0.47056 \\
\hline VZW-17S & Alluvium & $1.52 \mathrm{E}-06$ & 23.76 & 121.7 & 0.9 & 0.80 & 0.9 & 0.8 & 0.52149 \\
\hline OHS-21 & Overburden & $8.79 \mathrm{E}-07$ & 12.36 & 205.1 & 1 & 0.93 & 1 & 1 & 0.93974 \\
\hline VZW-25A & Overburden & $2.71 \mathrm{E}-06$ & 3.12 & 74 & 1 & 0.95 & 1 & 1 & 0.95784 \\
\hline VZW-31 & Quartz Monzonite & 9.57E-07 & 118.59 & 347.9 & 0.5 & 0.65 & 0.5 & 0.2 & 0.03296 \\
\hline
\end{tabular}




\begin{tabular}{|c|c|c|c|c|c|c|c|c|c|}
\hline Hole ID & Lithology & $\begin{array}{c}\text { K Packer \& } \\
\text { Slug Test }(\mathbf{m} / \mathbf{s})\end{array}$ & $\begin{array}{c}\text { Point } \\
\text { Test }\end{array}$ & $\begin{array}{c}\text { Total } \\
\text { Depth } \\
(\mathbf{m}) \\
\end{array}$ & 1-(RQD/100) & DI & 1-GCD & LPI & $\mathrm{HC}$ \\
\hline VZW-58 & Quartz Monzonite & $1.38 \mathrm{E}-06$ & 329.09 & 700 & 1 & 0.52 & 1 & 0.7 & 0.37091 \\
\hline VZW-74 & Quartz Monzonite & 3.97E-08 & 28.5 & 500 & 0.2 & 0.94 & 0.2 & 0.2 & 0.00754 \\
\hline VZW-50 & Quartz Monzodiorite & $3.76 \mathrm{E}-07$ & 277 & 399.6 & 0.4 & 0.30 & 0.4 & 0.1 & 0.00491 \\
\hline VZW-55 & Quartz Monzodiorite & $2.55 \mathrm{E}-07$ & 28.51 & 132.8 & 0.4 & 0.78 & 0.4 & 0.1 & 0.01257 \\
\hline VZW-62 & Quartz Monzodiorite & $1.74 \mathrm{E}-08$ & 87.14 & 200.2 & 0.5 & 0.56 & 0.5 & 0.1 & 0.01412 \\
\hline VZW-17 & Granodiorite & $1.17 \mathrm{E}-07$ & 280.5 & 432.5 & 0.1 & 0.35 & 0.1 & 0.1 & 0.00035 \\
\hline VZW-76 & Trachyandesite & 4.13E-08 & 94.18 & 300 & 0.1 & 0.68 & 0.1 & 0.1 & 0.00069 \\
\hline VZW-51 & Volcanic Breccia & $7.36 \mathrm{E}-07$ & 18.7 & 101.5 & 0.8 & 0.81 & 0.8 & 0.3 & 0.15663 \\
\hline VZW-29 & Limestone & 7.53E-09 & 305.85 & 408.61 & 0.1 & 0.25 & 0.1 & 0.1 & 0.00025 \\
\hline VZW-29S & Limestone & $5.46 \mathrm{E}-08$ & 6.46 & 27.5 & 0.2 & 0.76 & 0.2 & 0.1 & 0.00306 \\
\hline VZW-40 & Limestone & $1.59 \mathrm{E}-06$ & 11.73 & 400 & 0.9 & 0.97 & 0.9 & 1 & 0.78625 \\
\hline VZW-49D & Limestone & 7.52E-07 & 14.6 & 550 & 0.6 & 0.97 & 0.6 & 0.5 & 0.17522 \\
\hline VZW-52 & Limestone & $1.09 \mathrm{E}-06$ & 11.4 & 267.45 & 0.9 & 0.95 & 0.9 & 1 & 0.77547 \\
\hline VZW-53A & Limestone & $2.82 \mathrm{E}-06$ & 27.5 & 489.8 & 0.9 & 0.94 & 0.9 & 1 & 0.76452 \\
\hline VZW-59 & Limestone & 7.05E-07 & 227.02 & 401 & 0.6 & 0.43 & 0.6 & 0.5 & 0.0781 \\
\hline VZW-63 & Limestone & $3.38 \mathrm{E}-06$ & 46.97 & 500 & 1 & 0.90 & 1 & 1 & 0.90606 \\
\hline VZW-68 & Limestone & $2.27 \mathrm{E}-06$ & 288.2 & 400 & 1 & 0.27 & 1 & 1 & 0.2795 \\
\hline VZW-69 & Limestone & $1.21 \mathrm{E}-06$ & 210.42 & 400 & 1 & 0.47 & 1 & 1 & 0.47395 \\
\hline VZW-71 & Sandstone & $2.06 \mathrm{E}-07$ & 307.58 & 351 & 0.3 & 0.12 & 0.3 & 0.9 & 0.01002 \\
\hline VZW-75 & Limestone & $3.01 \mathrm{E}-07$ & 164.61 & 350 & 0.5 & 0.52 & 0.5 & 0.5 & 0.06621 \\
\hline VZW-39 & Limestone & $2.04 \mathrm{E}-08$ & 152.62 & 300.8 & 0.2 & 0.49 & 0.2 & 0.1 & 0.00197 \\
\hline VZW-61 & Limestone & $7.36 \mathrm{E}-08$ & 87.8 & 375.2 & 0.2 & 0.76 & 0.2 & 0.1 & 0.00306 \\
\hline VZW-73 & Limestone & $5.29 \mathrm{E}-08$ & 71.65 & 450 & 0.2 & 0.84 & 0.2 & 0.1 & 0.00336 \\
\hline VZW-245 & Volcanic Breccia & $1.14 \mathrm{E}-08$ & 94.91 & 120 & 0.5 & 0.20 & 0.5 & 0.1 & 0.00523 \\
\hline VZW-244 & Limestone & $1.46 \mathrm{E}-07$ & 66.37 & 150 & 0.5 & 0.55 & 0.5 & 0.1 & 0.01394 \\
\hline
\end{tabular}

\subsection{Cluster of RQD and Lithology in Relation Cluster of Hydraulic Conductivity}

The primary objective of this study is to understand the relationship between the characteristics of the hydrogeological conditions in the field in relation to geological condition (lithology) and geotechnical condition (RQD) based on data from drilling. The results of hydraulic conductivity modeling according to Cahyadi et al (2015) were clustered in this study into two parts, namely the cluster based on the geotechnical data and the cluster based on the geological data.

Clustering of hydraulic conductivity based on the geotechnical data relies on the RQD. This is very important as the correlation of hydraulic permeability and the RQD is very high. Cluster partition was set up for 10 divisions with RQD value interval of $10 \%$ for each division. Table 3 shows the results of cluster of hydraulic conductivity based on geotechnical data.

Table 3. Results of clustering of hydraulic conductivity based on the geotechnical data (RQD)

\begin{tabular}{|c|c|c|c|}
\hline CLUSTER & RQD $(\%)$ & K MAX $(\mathrm{m} / \mathrm{s})$ & K MIN $(\mathrm{m} / \mathrm{s})$ \\
\hline A & $0-10$ & $1.97762 \mathrm{E}-06$ & $2.17989 \mathrm{E}-08$ \\
\hline B & $11-20$ & $1.6449 \mathrm{E}-06$ & $6.21718 \mathrm{E}-08$ \\
\hline C & $21-30$ & $1.44909 \mathrm{E}-06$ & $2.40253 \mathrm{E}-08$ \\
\hline D & $31-40$ & $1.12814 \mathrm{E}-06$ & $3.76736 \mathrm{E}-08$ \\
\hline E & $41-50$ & $4.6015 \mathrm{E}-07$ & $1.88798 \mathrm{E}-07$ \\
\hline F & $51-60$ & $7.19233 \mathrm{E}-07$ & $2.07084 \mathrm{E}-08$ \\
\hline G & $61-70$ & $*$ & $*$ \\
\hline H & $71-80$ & $*$ & $*$ \\
\hline I & $81-90$ & $2.3493 \mathrm{E}-07$ & $1.92339 \mathrm{E}-08$ \\
\hline J & $91-100$ & $*$ & $*$ \\
$*$
\end{tabular}


In this study, cluster analysis was based on the data along the Grasberg mine drill holes that have been recorded in the database. Accordingly, the value of RQD written in terms of the range of values. For example, in one of the holes of a depth of $0 \mathrm{~m}$ to of $31.6 \mathrm{~m}$ was defined as limestone breccia, with RQD values of 30-50\%, so that the value of RQD used for calculation of HC-System relies on the average RQD value of corresponding RQD range in the database. For example, the RQD value of a depth from $0 \mathrm{~m}$ to $31.6 \mathrm{~m}$ is $40 \%$. This condition leads to the unallocated RQD value in the cluster G, H, and J. However, if the modeling hydraulic conductivity was based on block model then the entire cluster will be allocated. Result clusters were shown in the Table 3 representing the distribution of maximum and minimum value of hydraulic conductivity. According to distribution of each cluster it can be analyzed how the distribution of hydraulic conductivity values at each cluster.

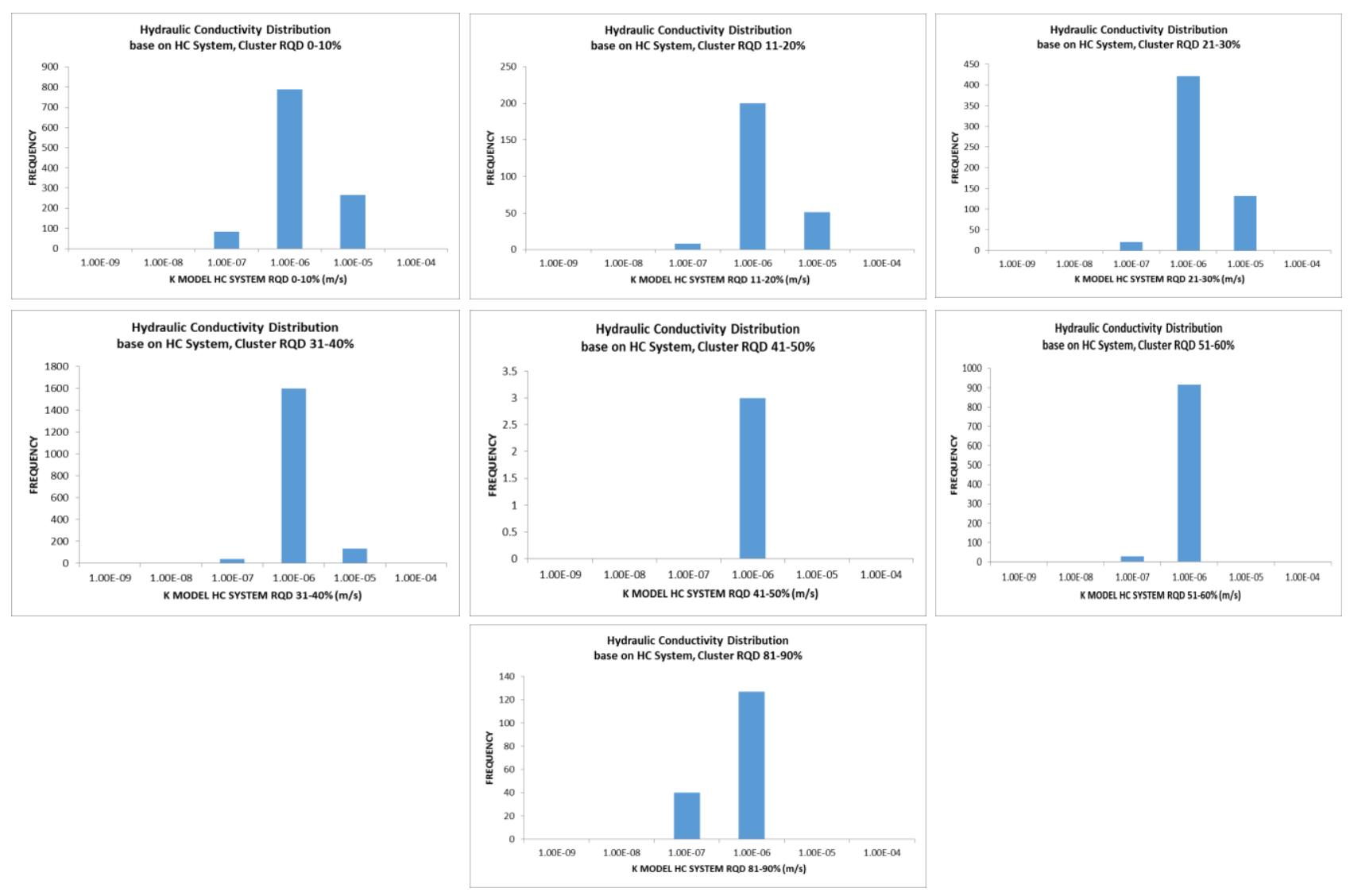

Figure 3. Hydraulic Conductivity Distribution

The RQD data can be grouped into three ranges, i.e. first group that dominates over $80 \%$ of the RQD data with $\mathrm{K}$ ranging between $1.9 \times 10^{-8}-2.3 \times 10^{-7} \mathrm{~m} / \mathrm{s}$, second group that is within $40-80 \%$ of the RQD data with $\mathrm{K}$ falling between $2 \times 10^{-8}-7.2 \times 10^{-7} \mathrm{~m} / \mathrm{s}$, and third group that takes part less than $40 \%$ of RQD data with $\mathrm{K}$ ranging between $2.1 \times 10^{-8}-1.9 \times 10^{-6} \mathrm{~m} / \mathrm{s}$. Table 2 and Table 3 show hydraulic conductivity and RQD from field investigation and HC-System Model, which resume bigger RQD with decreasing hydraulic conductivity.

The second cluster of hydraulic conductivity relies on geologic parameters. Based on Figure 2, lithology was converted to LPI and becomes the secondary parameter that influences the hydraulic conductivity. Clustering by the method of partition using the spead sheet EXCEL was based on the formula: VLOOKUP (COLUMNX-CODE-LPI ; COLUMNX-CODE-LPI : COUMNX-WEIGHT-LPI ; 2 ; FALSE ). If clustering of hydraulic conductivity was based on the lithology, there will be 26 clusters since there are 26 type of rocks in the database. By using filtering, the hydraulic conductivity of specific rock or lithology can be requested by inputing the corresponding rock or lithology, for example, hydraulic conductivity of andesite can requested by giving the andisite as the type of rock. Distribution of hydraulic conductivity based on the geology (lithology) can be seen in Table 4. 
Table 4. Results of clustering of hydraulic conductivity values based on the lithology

\begin{tabular}{|l|r|r|}
\hline \multicolumn{1}{|c|}{ CLUSTER } & \multicolumn{1}{c|}{ K MAX $(\mathrm{m} / \mathrm{s})$} & \multicolumn{1}{c|}{ K MIN $(\mathrm{m} / \mathrm{s})$} \\
\hline Andesite & $6.85633 \mathrm{E}-07$ & $1.92339 \mathrm{E}-08$ \\
\hline Trachyandesite & $2.5424 \mathrm{E}-07$ & $1.96979 \mathrm{E}-07$ \\
\hline Intrusive breccia & $2.86698 \mathrm{E}-07$ & $3.09222 \mathrm{E}-08$ \\
\hline Diorite & $6.38344 \mathrm{E}-07$ & $2.00356 \mathrm{E}-08$ \\
\hline Quartz diorite & $4.686 \mathrm{E}-07$ & $4.95415 \mathrm{E}-08$ \\
\hline Quartz diorite porphyritic & $2.25776 \mathrm{E}-07$ & $1.04837 \mathrm{E}-07$ \\
\hline Quartz monzonite & $1.25622 \mathrm{E}-07$ & $1.25622 \mathrm{E}-07$ \\
\hline Tuff & $9.08473 \mathrm{E}-07$ & $9.08473 \mathrm{E}-07$ \\
\hline Alluvium & $1.91982 \mathrm{E}-06$ & $1.12049 \mathrm{E}-07$ \\
\hline Colluvium & $1.93375 \mathrm{E}-06$ & $4.51454 \mathrm{E}-07$ \\
\hline Rehandle Material & $1.97762 \mathrm{E}-06$ & $2.17989 \mathrm{E}-08$ \\
\hline Sedimentary breccia & $6.36111 \mathrm{E}-07$ & $4.22845 \mathrm{E}-07$ \\
\hline Tectonic breccia & $1.07434 \mathrm{E}-06$ & $4.30392 \mathrm{E}-07$ \\
\hline Conglomerate & $1.00346 \mathrm{E}-06$ & $9.07384 \mathrm{E}-07$ \\
\hline Clay & $7.55858 \mathrm{E}-07$ & $7.06612 \mathrm{E}-07$ \\
\hline Dolomite & $7.7066 \mathrm{E}-07$ & $7.7066 \mathrm{E}-07$ \\
\hline Gravel & $1.45366 \mathrm{E}-06$ & $8.90272 \mathrm{E}-08$ \\
\hline Limestone & $1.63791 \mathrm{E}-06$ & $4.08755 \mathrm{E}-08$ \\
\hline Limestone breccia & $1.97312 \mathrm{E}-06$ & $6.0957 \mathrm{E}-08$ \\
\hline Dolomitic limestone & $1.14824 \mathrm{E}-06$ & $1.9447 \mathrm{E}-07$ \\
\hline Sandy limestone & $1.06672 \mathrm{E}-06$ & $5.54575 \mathrm{E}-07$ \\
\hline Shale & $4.11499 \mathrm{E}-07$ & $4.11499 \mathrm{E}-07$ \\
\hline Sandstone & $1.90922 \mathrm{E}-06$ & $1.89878 \mathrm{E}-07$ \\
\hline Limestone sandstone & $9.68645 \mathrm{E}-07$ & $9.68645 \mathrm{E}-07$ \\
\hline Sandstone breccia & $8.2061 \mathrm{E}-07$ & $7.34794 \mathrm{E}-07$ \\
\hline Limey sandstone & $1.06672 \mathrm{E}-06$ & $5.54575 \mathrm{E}-07$ \\
\hline
\end{tabular}

Based on the geological structure, Grasberg main rock is sedimentary rocks that is intruded by igneous intrusions. The intersection of several faults in the sedimentary rocks lead to fractured rock conditions. The presence of groundwater in horizontal drilling indicates the variation of lithologies, but the groundwater is mainly controlled by fractured limestone of Kais Formation. By comparing the observed and modeled measured hydraulic conductivity according HC-System, it can be showed that the distribution of hydraulic conductivity values in sedimentary rocks have a range of values ranging from $10^{-8}-10^{-6} \mathrm{~m} / \mathrm{s}$. It is clear that the hydraulic conductivity modeled acording to HC-System is closely matched to the observed value. It is different from sedimentary rock, igneous rock has a different range of observation value compared with that according to HC-System. Observation value indicates that the distribution of hydraulic conductivity of igneous rock ranges from $10^{-8}$ to $10^{-6} \mathrm{~m} / \mathrm{s}$, whereas the results according to HC-System varies between $10^{-8}-10^{-7} \mathrm{~m} / \mathrm{s}$. This is due to very low weight of LPI value used in the modeling, i.e. only around $0.1-0.15$. Since the RQD values has greatest influence on the hydraulic conductivity then the modeled hydraulic conductivity value are more proportional to RQD value as indicated by Table 2 . This condition gives the sense that the flow of water in locations is affected by fractured media, instead of porous media.

\section{Conclusions}

The result of the study demonstrate that:

- HC-System approach can be used to demonstrate relationship between hydrogeological (hydraulic conductivity), geological condition (lithology) and geotechnical condition (RQD).

- Based on the RQD data, the hydraulic conductivity can be grouped into three groups, i.e. first group that dominates over $80 \%$ of the RQD data with $\mathrm{K}$ ranging between $1.9 \times 10^{-8}-2.3 \times 10^{-7} \mathrm{~m} / \mathrm{s}$, second group that is within $40-80 \%$ of the RQD data with $\mathrm{K}$ falling between $2 \times 10^{-8}-7.2 \times 10^{-7}$ $\mathrm{m} / \mathrm{s}$, and third group that takes part less than $40 \%$ of RQD data with $\mathrm{K}$ ranging between $2.1 \times 10^{-8}$ $-1.9 \times 10^{-6} \mathrm{~m} / \mathrm{s}$. 
- Based on the lithology, the hydraulic conductivity of rocks can be assinged as follows: igneous rock with $\mathrm{K}$ ranging $6.8 \times 10^{-8}-1.9 \times 10^{-7} \mathrm{~m} / \mathrm{s}$, and sedimentary rock with $\mathrm{K}$ ranging $2.2 \times 10^{-8}$ $1.9 \times 10^{-6} \mathrm{~m} / \mathrm{s}$

\section{Acknowledgements}

The authors would also acknowledge PT. Freeport Indonesia for permit, provide research and provision of the data. Secondly, thank to Dr. Zuher Syihab, Irwan Iskandar Ph.D and Mining Hydrogeology Laboratory ITB for their support on writing this paper.

\section{Reference}

Antoro, B., Margotomo, W., Perdana, A., Widijanto, E., Wiwoho. N., Ginting, A.P., Santosa, R.G.I., Pramuji, Silaen, H., Setyadi, H., Iribaram, F., Mundu, S., Garjito, W., Sumarwan, F., Rohmadi, A., Setiadi, T., Afwan, A., Asrizal., Pahala, A.R., Prasetyo, N., 2011, Geology and Geotechnic Grasberg Open Pit Mining, PTFI (in Bahasa Indonesia), Aksara Buana.

Cahyadi T.A., Widodo L.E., Iskandar I., Sukaerang, Suyono., 2015, Modeling Spatial Distribution of 3D Isotropic Hydraulic Conductivity Based on HC-System for Fractured Groundwater Flow Media using Neural Network Case Study Grasberg Open Pit of PTFI and Surrounding., International Symposium on Earth Science and Technology, Japan, pp 59-64.

Deere, D.U., Hendron, A. J., Patton, F. D., Cording, E. J., 1967, Design of Surface and Near Surface Construction., In Rock, Proceedings of 8th U.S. Symposium. Rock Mechanics, AIME, New York, pp 237-302.

Deere D.U., 1989, Rock quality designation (RQD) after 20 years, U.S. Army Corps of Engineers Contract Report GL-89-1., Vicksburg, MS: Waterways Experimental Station.

Hsu, S., Lo H., Chi, S., Ku, C., 2011, Rock Mass Hydraulic Conductivity Estimated By Two Empirical Models., In: Dikinya $O(e d)$ Developments in hydraulic conductivity research, InTech, New York., pp 134-158.

Jain A, K., Murty M,N., Flynn P,J., 1999, Data clustering: a review., ACM Comput Surv, v31:, pp 264-323.

Lee C.H., Farmer I., 1993, Fluid Flow in Discontinuous Rocks., Chapman \& Hall, London, UK.

Mayer J.M., Allen D.M., Gibson H.D., Mackle D.C., 2014, Application of Statistical Approach to Analyze Geological, Geotechnical and Hydrogeological Data at a Fracture-Rock Mine Site in Northern Canada., Hydrogeological Journal, DOI.10.1007/s10040-014-1140-2.

Sapiie, B., 1994, Structural Geologic Studies Along Heat Road And Grasberg Area in The Ertsberg (Gunung Bijih) Mining District, Irian Jaya, Indonesia., Department of Geological Sciences University of Texas at Austin. 